ADDIN, Volume 13, Number 1, February 2019

\title{
Measuring Perceived e-Services Quality on Satisfaction of Islamic Saving and Credit Cooperatives (ISCC)
}

\section{Ekawati Rahayu Ningsih}

Institut Agama Islam Negeri (IAIN) Kudus, Indonesia

ekawati@iainkudus.ac.id

Tulus Haryono

Universitas Sebelas Maret Surakarta, Indonesia tulus_fe_uns@yahoo.com

\section{Hunik Sri Runing Sawitri}

Universitas Sebelas Maret Surakarta, Indonesia

hunik_sri@yahoo.co.id

\section{Mugi Harsono}

Universitas Sebelas Maret Surakarta, Indonesia mugiharsono@gmail.com

\section{Abstract}

This research aims to measure e-Service Quality of banking on Islamic Saving and Credit Cooperatives (ISCC) satisfaction. Nowadays, banking is in global business which prioritizes electronic services based on information technology advancement. This field research by using quantitative analysis was based on primary data from 299 respondents of ISCC in Central Java. The findings of data test by using PLS Version 3.0 showed that e-Service Quality influenced ISCC satisfaction. It was shown by lane coefficient of e-Service Quality to satisfaction and its significance was 0.461 . This significance to alpha was 0.05 . Then, since score of its t-statistic was $7.754^{*}$ higher than 
Ekawati Rahayu Ningsih, dkk.

ttable $=1.65$, then it showed that e-Service Quality influenced positively to satisfaction.

Keyword: E-Services Quality, Satisfation, Islamic Saving and Credit Cooperatives.

\section{Abstrak}

MENGUKUR PENGARUH E-SERVICES QUALITY PADA KEPUASAN KOPERASI SIMPAN PINJAM PEMBLAYAAN SYARI'AH. Tujuan penelitian ini adalah untuk mengukur pengaruh e-Services Quality perbankan pada kepuasan Koperasi Simpan Pinjam Pembiayaan Syari'ah (KSPPS). Pada saat ini perbankan berada pada bisnis global yang mengutamakan pada pelayanan elektronik berbasis pada kemajuan teknologi informasi. Jenis penelitian ini adalah Field Research dan menggunakan analisis kuantitatif berbasis pada data primer dari responden berjumlah 229 KSPPS di Provinsi Jawa Tengah. Hasil pengujian data menggunakan PLS Versi 3.0 menunjukkan bahwa e-Services Quality perbankan berpengaruh pada kepuasan KSPPS. Hal ini ditunjukkan dari besaran koefisien jalur e-Services Quality terhadap kepuasan dan signifikansinya adalah 0,461 dan signifikan terhadap alpha 0,05 , dan karena nilai t statistiknya 7,754* lebih besar dari nilai t tabel 1,65 maka menunjukkan bahwa e-Services Quality berpengaruh positif terhadap kepuasan.

Kata Kunci: E-Services Quality, Kepuasan, Koperasi Simpan Pinjam Pembiayaan Syariah.

\section{A. Introduction}

The banking success, one of them, is depended on e-Service Quality perception from business clients. ${ }^{1}$ It is due to e-Service Quality becomes strategic key in banking success which operates in

1 R.C. Caceres and N.G. Paparoidamis, "Service Quality, Relationship Satisfaction, Trust, Commitment and Business-to-business Loyalty", European Journal of Marketing 41, no. $7 / 8$ (2007): 836-867. 
global market. ${ }^{2}$ E-Service Quality is a logic pioneer to create clients' satisfactions. ${ }^{3}$ The implementation of e-Service Quality will facilitate access and service for the clients. Because of its importance, then the discussion and evaluation dealing with this area are important to do.

The Indonesian government has regulated banking e-Service Quality by issuing several regulations including Bank Indonesia Regulation No. 9/15/PBI/2007 concerning Application of Risk Management in the Use of Information Technology by Commercial Banks. Furthermore, Bank Indonesia Regulation No. 18/40/ PBI/2016 concerning the Implementation of Payment Transaction Processing. The two important regulations are the basis and at the same time driving the implementation of banking e-Service Quality in Indonesia. $^{4}$

Financial Service Authority (OJK) accounted the users of e-Service Quality (SMS Banking, Internet Banking, Credit/Debit Card, ATM, PayPal, t-Cash) increased 270\% from 13.6 million clients in 2012 into 50.4 million clients in 2016. Frequency of the clients' transactions by using e-Banking increased $169 \%$ from 150.8 million transactions in 2012 into 405.4 million in 2016. ${ }^{5}$ However, survey by APJJ in 2017 also showed that those utilizing internet as banking transaction facility was $17.04 \%$ so empirical gap occurred. ${ }^{6}$

2 Rajaobelina Ricard Brun, "Online Relationship Quality: Testing an Integrative and Comprehensive Model in the Banking Industry", Journal of Relationship Marketing 15, no. 4 (2016): 219-246.

3 K.G. Boakye, V.R. Prybutok, and C. Blankson, "An Integrated Model of Quality for Mass Services in the Context of the Ghanaian Retail Banking Sector", Thunderbird International Business Review 58, no. 5 (2016): 425-438.

4 A. Sakti, "Mapping of Conditions and Potential of BMT: Partnership to Expand the Market and Linkage of Islamic Banking Service to Micro Enterprise", Jurnal al-Muzara'ab 1, no. 1 (2013): 1-18.

5 Asosiasi Penyelenggara Jasa Internet Indonesia, "Perilaku Pengguna Internet Indonesia: Infografis Penetrasi dan Perilaku Pengguna Internet Indonesia", Hasil Survey, 2016, 26-27.

6 Asosiasi Penyelenggara Jasa Internet Indonesia, "Pertumbuhan Pengguna Internet Indonesia: Infografis Penetrasi dan Perilaku Pengguna Internet Indonesia", Hasil Survey, 2017, 6-2. 
The previous studies showed minimum numbers of micro enterprise clients in utilizing internet as meant to do banking transaction since unfriendly e-Banking Platform services, slow transfer through e-Banking, expensive service cost in the first year, The level of knowledge of business customers and bank employees about low e-Service Quality services. ${ }^{7}$

Unit analysis of this research is Islamic credit, saving, and financial cooperative (ISCC) because it is micro financial institution which becomes primary strength and motivator for banks to innovate in service system and its product. ${ }^{8}$ Then, ISCC has product needs and complex banking services. However, the facts showed they were not fully covered by bank. ${ }^{9}$ Several empirical phenomena become hindrances of micro enterprise or ISCC in receiving E-Service Quality maximally. By considering this importance of the discussion, then this research identifies main elements of e-Service Quality perception and assess its significance to ISCC' satisfaction.

Conceptually, the discussion dealing with natures, outcomes, and complete influence of e-Service Quality to satisfaction must be further reviewed because there are still many research's differences, especially in developing country i.e, Indonesia. ${ }^{10}$ It caused findings which became evaluative criteria and processes used in forming ISCC perception about e-Service Quality toward satisfaction in Indonesia were still limited and not conclusive. The gap of previous studies are presented on Table 1.

7 Abdullahu Mullatahiri and Podvorica, "The Approach of Local Firms towards e-Banking, Iliria International Review, no. 1 (2015): 149-161.

8 M.A. Adnan and S.R. Ajija, "The Effectiveness of Baitul Maal wat Tamwil in Reducing Poverty: the Case of Indonesian Islamic Microfinance Institution" Humanomics 31, no. 2 (2015): 160-182.

9 M. Sakai, "Establishing Social Justice through Financial Inclusivity: Islamic Propagation by Islamic Saving and Credit Cooperatives in Indonesia", TRaNS: TransRegional and-National Studies of Southeast Asia 2, no. 2 (2014): 201-222.

10 R.C. Caceres and N.G. Paparoidamis, "Service Quality, Relationship Satisfaction, Trust, Commitment and Business-to-business Loyalty", European Journal of Marketing 41, no. 7/8 (2007): 836-867. 
Table 1

Previous Research Conclusions

about the Effect of Perception of E-Services Quality on Satisfaction

\begin{tabular}{|c|c|c|c|c|}
\hline \multirow{2}{*}{ No. } & \multicolumn{2}{|c|}{ Variabel } & \multirow{2}{*}{ Result } & \multirow{2}{*}{$\begin{array}{c}\text { Researcher and } \\
\text { Year }\end{array}$} \\
\hline & Independen & Dependen & & \\
\hline \multirow{2}{*}{1} & \multirow{2}{*}{$\begin{array}{l}\text { E-Services } \\
\text { Quality }\end{array}$} & \multirow{2}{*}{ Satisfaction } & $\begin{array}{l}\text { Positive and } \\
\text { significant }\end{array}$ & $\begin{array}{l}\text { Caceres and } \\
\text { Paparoidamis, } 2007\end{array}$ \\
\hline & & & Not significant & $\begin{array}{l}\text { Dick and Basu, } \\
1994\end{array}$ \\
\hline
\end{tabular}

Source: Extracted from various research journals.

Based on Table 1, the gap of this research are: e-Service Quality positively and significantly influenced satisfaction. ${ }^{11}$ In contrast, Dicky and Basu (1994) argued e-Service Quality did not influence satisfaction. To overcome the research gap, Caceras and Paparoidamis suggested for future researchers to use SERPERV measurement model as alternative measuring model in measuring e-Service Quality perception. ${ }^{12}$

Therefore, based on the background, the gap and the suggestion of the previous studies, this research aims to test empirically e-Service Quality perception on satisfaction. The gap of this research is handled by dimension identifying steps of e-Service Quality perception through analysis of important actual performance or known as SERVPERF. ${ }^{13}$ The assumption was, when ISCC received e-Service Quality, each of them had different need priority so it would influence to different perception and evaluation toward e-Service Quality. Therefore, SERVPERF measurement model becomes this research measuring model to recognize important factors in e-Service Quality according to ISCC perspectives. ${ }^{14}$

11 R.C. Caceres and N.G. Paparoidamis.

12 A.S. Dick and K. Basu, "Customer Loyalty: toward an Integrated Conceptual Framework", Journal of the Academy of Marketing Science, 1994.

13 M. Hemmasi, K. Strong, and S. Taylor, "Measuring Service Quality for Strategic Planning and Analysis in Service Firms", Journal of Applied Business Research 10, no. 4 (1994): 24.

14 M. Joseph and G. Stone, "An Empirical Evaluation of US Bank Customer Perceptions of the Impact of Technology on Service Delivery in the Banking Sector", International Journal of Retail and Distribution Management 31, no. 4 (2003): 190-202. 
This research is expected to theoretically and practically contribute. The findings by using SERVPERF measuring model to find out e-Service Quality perspective were expected to enrich this research's findings which investigated relationship marketing between ISCC and Banks. The findings were expected to be useful practically for banks in measuring ISCC' satisfaction on e-Service Quality performance.

\section{B. Discussion}

\section{E-Services Quality}

E-Service Quality is a term used to describe electronic trading transaction services among companies or known as B2B service quality. Zeithaml et al stated that $\mathrm{B} 2 \mathrm{~B}$ as service quality delivery through website can be used as an adjective to describe business activities among companies, both product markets and $e$-Business based services. ${ }^{15}$

E-Service Quality provides many benefits for clients, banks, and other authority parties. For clients, e-Service Quality could provide accessibility of transaction dealing with time, place, and cost. ${ }^{16}$ Clients also do not need to come to a Bank to get further information or having banking transaction. Even, for several e-SQ products, clients can do it anytime, 24 hours, by using laptop or mobile devices, such as mobile phone which can be brought anywhere as long as it is connected to internet or SMS. ${ }^{17}$

Conceptualization and measurement of e-Service Quality perception in contemporary theory are still debatable and

15 L.L. Berry, “On Great Service: a Framework for Action”, Free Press (New York: n.p., 1995).

16 M. Joseph and G. Stone, "An Empirical Evaluation of US Bank Customer Perceptions of the Impact of Technology on Service Delivery in the Banking Sector", International Journal of Retail and Distribution Management 31, no. 4 (2003): 190202.

17 Sorooshian, S. Salimi, M. Salehi, M. Nia, N. Bekheir, Asfaranjan, and Y. Sazmand, "Customer Experience about Service Quality in Online Environment: a Case of Iran”, Journal of Procedia, Social and Behavioral Sciences 93, no. 1 (2013): 168-169. 
controversial in many marketing service literatures. ${ }^{18}$ Several experts defined service quality differently. The beginning of service quality definition was based on disconfirmation theory or called paradigm theory. According to Parasuraman, Zeitham, and Berry, they argued that service quality perception were comparison results of what consumers considered to how a service should be and their perception about actual performance offered by service provider. ${ }^{19}$

Hemmasi and Joseph developed alternative measuring model known as SERVPERF model. It focuses only on actual performance. $^{20}$ Since then, there have been several researchers, such as Vilares and Coelho found that expectation did not always directly influence satisfaction. Their arguments lately supported SERVPERF model. ${ }^{21}$

\section{Satisfaction}

To reach highest level of customer satisfaction is main purpose of marketing. Nowadays, there are many concerns expressed on "total" satisfaction concept in which its implications deal only with partial satisfaction will never make customers to be loyal and come to visit again. When customers are satisfied to a service or good, they will be highly possible to return and to buy again. ${ }^{22}$

Influence of e-Service perception to satisfaction is developed from Caceres and Paparoidamis' research (2007). The research determined one of the most important element in $\mathrm{B} 2 \mathrm{~B}$ market was company success in developing qualified relationship to clients by improving satisfaction. Satisfaction in business context is defined

18 M.K. Brady and J.J. Cronin, Jr., "Some New Thoughts on Conceptualizing Perceived Service Quality: a Hierarchical Approach”, Journal of Marketing 65, no. 3 (2001): 34-49.

19 A. Parasuraman, V.A. Zeitham, and L.L. Berry, "A Conceptual Model of Service Quality and Its Implication for Future Research", Journal of Marketing 49, no. 4 (1985).

20 J. M. Vilares and S.P. Coelho, "The Employee-Customer Satisfaction Chain in the ECSI Model”, European Journal of Marketing 37, no. 11/12 (2003): 1.703-1.722.

21 J.M Vilares and S.P. Coelho.

22 P. Kotler and K.L. Keller, Marketing Management Organization, Volume 22, 2006. 
as positive affective condition which is resulted from company's judgment toward all aspects of cooperation with other companies. ${ }^{23}$ Three levels of satisfaction strongly contribute to marketing relationship completely. According to Crosby and Stevens, they were personal interaction, main service, and organization. ${ }^{24}$

Study development in relationship marketing states that satisfaction is cumulative impacts experienced by consumers during their relationship and are not as the results of certain partial transaction. ${ }^{25}$ Caceres and Paparoidamis, in their research stated that the cumulative impacts experienced by B2B led to satisfaction. Their findings were strengthened by previous investigations, such as Anderson, et al. (1994), Cronin and Taylor (1992), Dick and Basu $(1994) .{ }^{26}$

Although service quality correlation to satisfaction is important but satisfaction cannot automatically lead consumers to repurchase since to decide is closely correlated by several factors, both internal and external. It may influence consumers' decisions. ${ }^{27}$ The previous findings showed that e-Service Quality positively influenced B2B satisfaction in relationship marketing. Thus, the proposed hypothesis is:

H1: Perception of e-Service Quality has a positive effect on KSPPS satisfaction.

23 J.C. Anderson and J.A. Narus, "A Model of Distributor Firm and Manufacturer Firm Working Partnerships", Journal of Marketing 54, no. 1 (1990): 42-58.

24 P.B. Crosby, Quality is Free: the Art of Marketing Quality Certain (n.p.: Mc Graw Hill Book Company, 1979).

25 J.C. Anderson and J.A. Narus, "A Model of Distributor Firm and Manufacturer Firm Working Partnerships", Journal of Marketing 54, no. 1 (1990): 42-58.

26 R.C. Caceres and N.G. Paparoidamis, "Service Quality, Relationship Satisfaction, Trust, Commitment and Business-to-business Loyalty", European Journal of Marketing 41, no. 7/8 (2007): 836-867.

27 F.F. Reichheld and K. Aspinall, "Building High-Loyalty Business System", Journal of Retail Banking 15, no. 4 (1993): 21-9. 


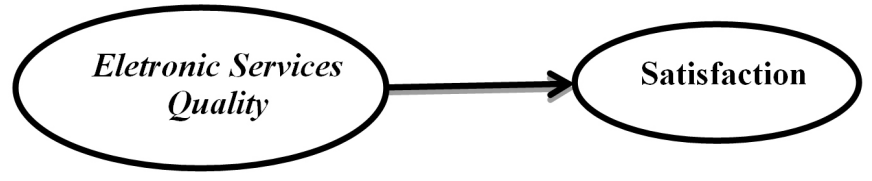

Figure 1

\section{Research Conceptual Framework ${ }^{28}$}

\section{Methode}

E-Service Quality perception is measured by 5 range Likert scale from extremely disagree until strongly agree. The indicators of the independent variable, e-Service Quality, is based on SERVPERF scale measurement, consisting of 6 dimension and 25 indicators as shown in Table 2.

The population of the research consisted of listed ISCC in Minister of Cooperation, SMME, and becoming members of PBMTI Central Java. Based on time series data of the ministry within fourth-three months in 2017, the total of active cooperative in Central Java was 21.455 (Central Java SMME Service, 2017). Meanwhile, those which were active as members of PBMTT in 2018 were 360 ISCC.

The representing sample size in Structural Equation Modeling Analysis (SEM) should be five times of the used indicators. ${ }^{29}$ The numbers of valid indicators from quality of electronic services were 25 items while satisfaction 3 items. Based on SEM assumption, then the number of the research minimum sample is 140 (28 x 5). The source of information respondents consisted of one representative of each ISCC in transacting with bank. They might be first manager, secretary, or treasurer. To ease the data collection, the author used WhatsApp and e-mail to distribute the questionnaire.

28 R.C. Caceres and N.G. Paparoidamis, "Service Quality, Relationship Satisfaction, Trust, Commitment and Business-to-business Loyalty", European Journal of Marketing 41, no. 7/8 (2007): 836-867.

29 J.F. Hair, J.G.T.M. Hult, C.M. Ringle, and M. Sarstedt, "Partial Least Squares Structural Equation Modeling (PLS-Sem)”, 2014. 
Ekawati Rahayu Ningsih, dkk.

Table 2

Variable, Definitions, Dimensions, Indicators, and

Measurement Scale

\begin{tabular}{|c|c|c|c|c|c|}
\hline No. & Variable & Definitions & Dimensions & Indicators & Scale \\
\hline \multirow[t]{6}{*}{1} & $\begin{array}{l}\text { E-Services } \\
\text { Quality }\end{array}$ & $\begin{array}{l}\text { Services for } \\
\text { electronic trade } \\
\text { transactions } \\
\text { between banks } \\
\text { and business } \\
\text { institutions or } \\
\text { known as B2B } \\
\text { service quality } \\
\text { (Hemmasi, 1994; } \\
\text { Joseph, 2006) }\end{array}$ & $\begin{array}{l}\text { Accuracy/ } \\
\text { comfort }\end{array}$ & $\begin{array}{l}\text { 1. Choice of many } \\
\text { menus } \\
\text { 2. Fast and accurate } \\
\text { 3. It's easy to } \\
\text { rationalize } \\
\text { 4. Convenient to use } \\
\text { 5. Effective and } \\
\text { efficient process } \\
\text { 6. Notifications in } \\
\text { each transaction } \\
\text { 7. The loading system } \\
\text { is not long }\end{array}$ & $\begin{array}{l}\text { Likert } \\
1-5\end{array}$ \\
\hline & & & Acessibility & $\begin{array}{l}\text { 1. Safe and reliable } \\
\text { 2. Language selection } \\
\text { menu } \\
\text { 3. Complete access } \\
\text { facilities } \\
\text { 4. Efforts to fulfill } \\
\text { satisfaction } \\
\text { 5. } 24 \text { hour complaint } \\
\text { handling }\end{array}$ & $\begin{array}{l}\text { Likert } \\
1-5\end{array}$ \\
\hline & & & $\begin{array}{l}\text { Queue } \\
\text { Management }\end{array}$ & $\begin{array}{l}\text { 1. There is music } \\
\text { entertainment } \\
\text { 2. There is advertising } \\
\text { and advertising } \\
\text { 3. Other relevant } \\
\text { information }\end{array}$ & $\begin{array}{l}\text { Likert } \\
1-5\end{array}$ \\
\hline & & & Personalization & $\begin{array}{l}\text { 1. Personalize in } \\
\text { service } \\
\text { 2. Recognition of } \\
\text { the existence of } \\
\text { customers } \\
\text { 3. Create your own } \\
\text { account } \\
\text { 4. There is a brochure } \\
\text { to study }\end{array}$ & $\begin{array}{l}\text { Likert } \\
1-5\end{array}$ \\
\hline & & & Responsive & $\begin{array}{l}\text { 1. Friendly service } \\
\text { 2. User friendly } \\
\text { 3. Online guidance } \\
\text { system } \\
\text { 4. Notification if the } \\
\text { system error }\end{array}$ & $\begin{array}{l}\text { Likert } \\
1-5\end{array}$ \\
\hline & & & $\begin{array}{l}\text { Service Quality } \\
\text { Target }\end{array}$ & $\begin{array}{l}\text { 1. Special services for } \\
\text { KSPPS } \\
\text { 2. Additional services } \\
\text { for KSPPS }\end{array}$ & $\begin{array}{l}\text { Likert } \\
1-5\end{array}$ \\
\hline
\end{tabular}




\begin{tabular}{llll}
\hline 2 Satisfaction & Satisfaction is as a & 1. Very satisfied with & Likert \\
customer response & e-Services Quality & $1-5$ \\
to the fulfillment & 2. Feel satisfied, right & \\
of needs (Oliver, & and right to use & \\
1997) & $\begin{array}{l}\text { e-Services Quality } \\
\text { 3. Trying to maintain } \\
\text { good relations with } \\
\text { the bank }\end{array}$ & \\
& & & \\
\hline
\end{tabular}

\section{Result}

There were 229 respondents. The instruments were considered valid when they had loading score higher than $0.7{ }^{30}$ First order CFA test result is shown on Table 3.

\section{Table 3}

\section{Outer Loading Test CFA First Order e-Services Quality and Satisfaction}

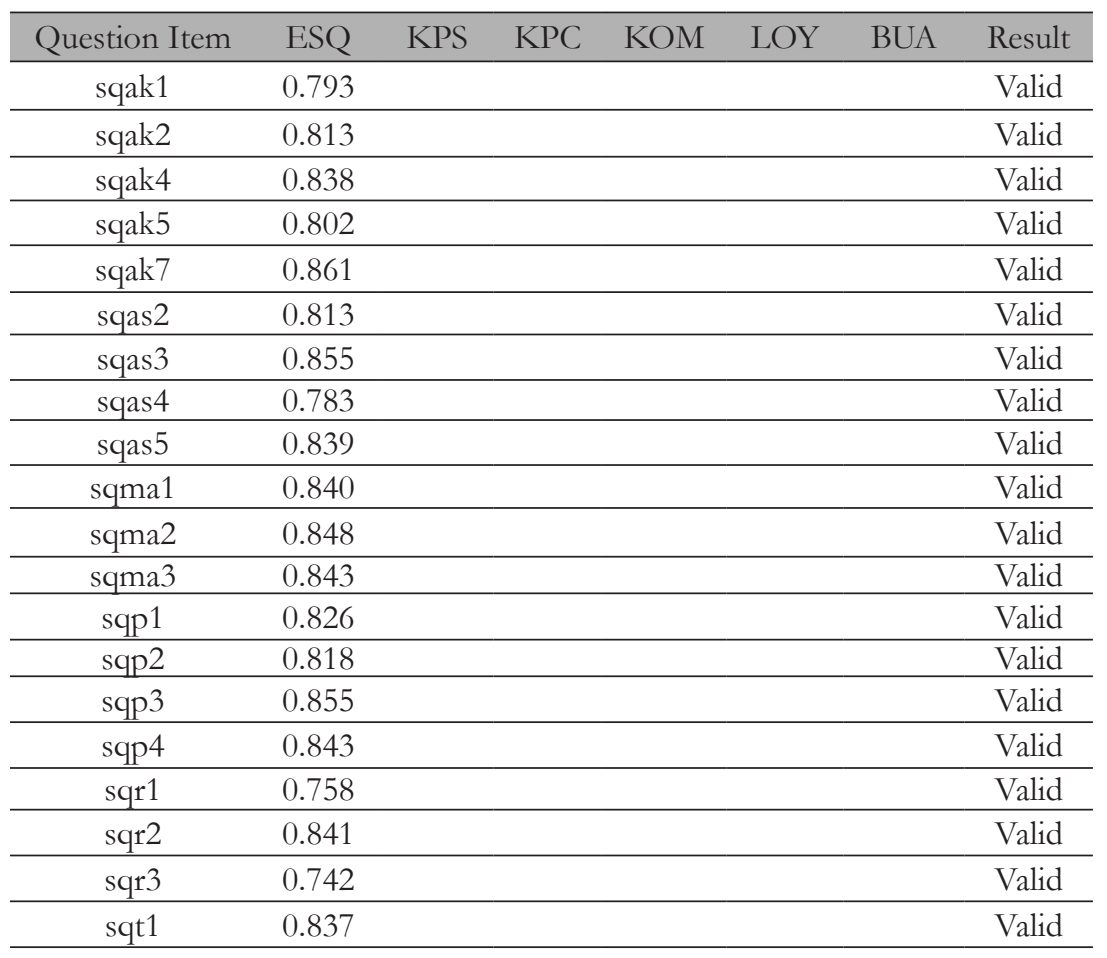

30 I. Ghozali and H. Latan, Structural Equation Modeling: Teori, Konsep, dan Aplikasi dengan Program Smart PLS 2.0 (Semarang: Badan Penerbit Universitas Diponegoro, 2011). 
Ekawati Rahayu Ningsih, dkk.

\begin{tabular}{|c|c|c|c|c|c|c|c|}
\hline Question Item & ESQ & KPS & KPC & $\mathrm{KOM}$ & LOY & $\mathrm{BUA}$ & Result \\
\hline sqt2 & 0.847 & & & & & & Valid \\
\hline kps01 & & 0.812 & & & & & Valid \\
\hline kps02 & & 0.841 & & & & & Valid \\
\hline kps03 & & 0.743 & & & & & Valid \\
\hline
\end{tabular}

Source: Primary Data Processed, 2018.

Table 3 shows all variables of e-Service Quality and satisfaction had loading factor score higher than 0.70 and were significant to 0.04 . The significant value was shown by $\mathrm{t}_{\text {statistic }}<\mathrm{t}_{\text {table, }}$ 0.65. It meant that all indicators of each variable had high convergent validity scores.

The reliability test was done by using second order CFA and rechecking the AVE coefficient score, composite reliability, and cronbach alpha as shown in Table 4. The used parameters to judge reliability were the AVE coefficient had to be higher than 0.50. Then, all of composite reliability and cronbach alpha of all variables had to be higher than $0.70 . .^{31}$

\section{Table 4}

\section{AVE, CR, CA, R Square}

\begin{tabular}{lcccc}
\hline Laten Variable & AVE & $\begin{array}{c}\text { Composite } \\
\text { Reliability }\end{array}$ & Cronbach Alpha & R Square \\
\hline E-Services Quality & 0.679 & 0.978 & 0.977 & \\
\hline Trust & 0.978 & 0.989 & 0.977 & 0.764 \\
\hline Satisfaction & 0.640 & 0.842 & 0.722 & 0.210 \\
\hline
\end{tabular}

Source: Primary Data Processed, 2018.

Second order CFA analysis results toward second step test of e-Service Quality and satisfaction showed that each variable had met the parameter of AVE coefficient higher than 0.50, Composite Reliability higher than 0.70, and Cronbach higher than 0.70. Thus, all variables were said to meet the reliability instrument criteria. The

31 I. Ghozali and H. Latan. 
instrument had shown accuracy, consistency, and appropriateness as measurements.

Then, hypothesis test was done. Its analysis was shown by coefficient of presented lane to Table 5 .

\section{Table 5}

\section{Path Coeffient Influence between Variables}

\begin{tabular}{ccccc}
\hline Path & Original Sample & $\begin{array}{c}\text { T Statistics } \\
(\text { O/STERR })\end{array}$ & P Value & Information \\
\hline ESQ => KPS & 0,461 & 7,754 & 0,000 & Significant \\
\hline
\end{tabular}

Source: Bootstrapping Analysis Results, 2018.

Based on the table, e-Service Quality influenced satisfaction. It was shown by value of e-Service Quality lane coefficient to satisfaction and its significance. The value of the coefficient lane was 0.461 and was significant to alpha 0.05 . Then, since the value of $t_{\text {statistic }}$ was $7.754^{*}$ greater than $\mathrm{t}_{\text {table }} 1.65$, it showed that e-Service Quality positively influenced satisfaction. Therefore, the hypothesis stating that e-Service Quality positively influenced satisfaction was statistically supported.

\section{Discussion}

Discussion result of the hypothesis covered influences of e-Service Quality to satisfaction. Several reasons which became the evidence and underlined e-Service Quality to have influence positively to ISCC satisfaction were due to highest mean of the respondents' answers on each dimension of e-Service Quality variable indicators. They were representatives of respondents' experience during using e-Service Quality.

In accuracy and convenience dimensions, the highest mean was shown on respondents' answers dealing with their feeling of effectiveness and efficiency during transaction by using e-Service Quality from both time and cost aspects. It is in line with Caceres and Paparoidamis (2007) stating that one of business consumer 
characteristics toward $\mathrm{B} 2 \mathrm{~B}$ market was to prioritize efficiency and effectiveness of service. It is also supported by number ten descriptive data of the respondents which stated that from $100 \%$ respondents (299 ISCC) were e-Service Quality facility users, started from ATM, RTGS, Internet Banking, SMS Banking, or Bank Link. It meant the ISCC had no difficulties in using e-Service Quality.

Overall, ISCC perception toward e-Service Quality showed that bank had provided menu selection in Service Quality properly. The transaction process was considered pretty accurate and appropriate. The electronic service was comfortable although it took longer time with short loading time. Those reasons made accuracy and convenience were percept sufficiently good by respondents. Thus, they were satisfied.

Dealing with accessibility dimension, the highest mean was shown by respondents' statements toward accessible facility completeness which was available in e-Service Quality. It was included additional service and Indonesian language selection for respondents whom did not speak English, whom were disable and elderly. This facility completeness made ISCC was satisfied on accessibility. Furthermore, most of the respondents were satisfied on the banking efforts to meet their needs proportionally through e-Service Quality and complaint handling for 24 hours. Based on average answers of the respondents completely, started from second indicator until fifth indicator of accessibility, e-Service Quality was sufficiently good.

On queue management, the highest mean was shown by respondents' answers upon question dealing with advertisement and advertising availability during waiting in the line. It made ISCC satisfied. Furthermore, most of the respondents admitted feeling satisfied because of kind and friendly e-Service Quality in which had music amusement during their waiting. Then, there were other relevant information. Overall, it can be stated that most of the respondents judged the queue management of the bank was sufficiently good. There were only few poor parts. Therefore, it can 
be stated that queue management was percept sufficiently good by ISCC.

On personalization dimension, the highest meant was shown by respondents' answers upon question dealing with acknowledgement of ISCC' existence toward electronic banking service period and brochure availability to learn independently. Those two factors made ISCC satisfied. Then, they were satisfied due to personalization in e-Service Quality and they had authorities to make their own accounts. Overall, most of respondents judged the e-Service Quality personalization efforts were sufficiently good. Only a few of them considered poor.

On responsiveness dimension, the highest mean was shown by respondents' answers to question dealing with notification or informational feedback toward ISCC when the e-Service Quality system was error. It made the ISCC satisfied. The respondents were also satisfied due to the bank effort in serving the ISCC well and kind, plus user-friendly. Overall, most of the respondents judged the responsibility of the bank toward ISCC was sufficiently good. Only a few of them considered it poor.

On target of service quality dimension, the highest mean was shown by the respondents' answers on question dealing with additional service availability for ISCC. It made them satisfied. They were also satisfied due to special service.

Based on the descriptive data of all respondents (299 ISCC) had good partnership with the bank both in financial allocation and fund. Thus, ISCC became important for the banks to develop relationship marketing so that there was a need of special service. Overall, most of respondents judged the banks' efforts in selecting target of service quality were sufficiently good. Only a few of them considered it poor. Therefore, it can be stated that target of service quality dimension was percept sufficiently good by ISCC.

The numbers of positive responses by KSPSS toward the indicators within each e-Service Quality dimension showed that they 
had really experienced good quality of electronic service quality from the banks. This condition was expected to create ISCC' satisfaction on bank. Therefore, better and qualified e-service quality, it would motivate ISCC to be satisfied and volunteer to come again and to have relationship marketing with the bank.

The findings are in line with disconfirmation paradigm theory (Oliver, 1997) stating that consumers would be satisfied when their perceptions were in line with expectation (confirmation reached). ${ }^{32}$ Then, Oliver also formulated in Gap Analysis Model that when performance of certain attribute improved greater than the expectation upon the attributes, then the perceptions toward service quality would be positive and in contrast. Dealing with e-Service Quality and ISCC' satisfaction, then ISCC had experienced e-Service Quality was very good and surpassed the expectation so they were satisfied. ${ }^{33}$

The findings were also consistent to Kotler and Keller's statements stating that antecedents of business clients' satisfaction were on service quality. ${ }^{34}$ The results of this study support the findings of Caceres and Paparoidamis, which states that e-services quality affects B2B satisfaction. ${ }^{35}$ The results of the study support the findings of Kumar and Shenbaragaman and Bapat which states that e-services quality affects the satisfaction of business customers. ${ }^{36}$ Wardono strengthened e-Service Quality influenced directly e-Satisfaction especially in developing countries. ${ }^{37}$

32 R. Oliver, Satisfaction: a Behavioral Perspective on the Consumer (New York: Mc Graw Hill International Editions, 1997).

33 P. Kotler and K.L. Keller, Marketing Management Organization, Volume 22, 2006.

34 P. Kotler and K.L. Keller.

35 R.C. Caceres and N.G. Paparoidamis, "Service Quality, Relationship Satisfaction, Trust, Commitment and Business-to-business Loyalty", European Journal of Marketing 41, no. 7/8 (2007): 836-867.

36 Bapat, "Exploring the Antecedents of Loyalty in the Context of Multi-Channel Banking”, International Journal of Bank. Marketing 35, no. 2 (2017): 174-186.

37 Wardono, "The Antecedent Factors on e-Loyalty Affecting the Generation $\mathrm{Y}$ in e-Commerce: a Cross-Cultural Study", Graduate Program in Economics Faculty of Economics and Business Universitas Indonesia Jakarta, 2015. 
Parasuraman, et al.; Reichheld and Sasser; Zeithaml, et al.; Dash, Bruning, and Guin; Rahman, Wan, and Ramli called e-Service Quality is important strategy for bank to succeed in competitive environment. ${ }^{38}$ Bank is able to offer qualified service quality for business clients, it would reach higher market share development. ${ }^{39}$ It also created satisfaction. ${ }^{40}$

In another hand, the findings did not support Kromidha and Kristo. They stated that relationship marketing, service quality had not exactly positively influenced satisfaction because business clients preferred not to use e-Service Quality from a bank exclusively but also from other banks. They did so because they expected to get more benefits and flexibility. ${ }^{41}$ They also stated that e-Service Quality had not exactly influenced satisfaction because satisfaction was result of all experiences of clients or called as cumulative satisfaction. ${ }^{42}$

Dixon, et al. (2005) stated that cumulative satisfaction consisted of product, interpersonal, and performance satisfaction. Consumers were satisfied on the product completely but they were not surely satisfied on other aspects, such as service or price. ${ }^{43}$ Cumulative satisfaction was assumed better as predictor of economy performance, further behavior, and loyalty of clients. ${ }^{44}$

38 M.A. Rahman, C.Y. Wan, and M.F. Ramli, "Relationship Quality as Mediator between Perceived Value and Customer Loyalty: Evidence from Dual-Window Banks in Northern Peninsular Malaysia", Ponte 72, no. 12 (2016): 370-379.

39 R.C. Caceres and N.G. Paparoidamis, "Service Quality, Relationship Satisfaction, Trust, Commitment and Business-to-business Loyalty", European Journal of Marketing 41, no. 7/8 (2007): 836-867.

40 Liu, Guo, and Lee, "The Effects of Relationship Quality and Switching Barriers on Customer Loyalty", Journal of Information Management, 2010.

41 Curtis, "Customer Satisfaction, Loyalty, and Repurchase: Meta-Analytical Review, Theoretical, and Empirical Evidence of Loyalty and Repurchase Differences", NSU Library, 2009.

42 A. Yeow, and W.K. Lim, "KOMIDA: Making Microfinance Digital in Indonesia: Theacing Case", Thirty Ninth International Conference on Information System, San Francisco, 2018.

43 R.C. Caceres and N.G. Paparoidamis, "Service Quality, Relationship Satisfaction, Trust, Commitment and Business-to-business Loyalty", European Journal of Marketing 41, no. 7/8 (2007): 836-867.

44 R.C. Caceres and N.G. Paparoidamis. 
Ekawati Rahayu Ningsih, dkk.

\section{Conclusion}

This research aims to find out and understand how ISCC' satisfaction could be fostered through antecedent factors, such as e-Service Quality. The conclusion of the research was based on hypothesis test in which the result was e-Service Quality positively influenced ISCC' satisfaction. Dealing with accuracy and convenience dimension, especially waiting time during service which became main priority considered by ISCC while using e-Service Quality. It was due to ISCC is business institution prioritizing time efficiency in business transaction activity. Therefore, it is suggested for banks to prioritize ISCC in their services. 


\section{REFERENCES}

Adnan, M.A. and S.R. Ajija. "The Effectiveness of Baitul Maal wat Tamwil in Reducing Poverty: the Case of Indonesian Islamic Microfinance Institution" Humanomics 31, no. 2 (2015): 160182.

Anderson, J.C. and J.A. Narus. "A Model of Distributor Firm and Manufacturer Firm Working Partnerships", Journal of Marketing 54, no. 1 (1990): 42-58.

Asosiasi Penyelenggara Jasa Internet Indonesia. "Perilaku Pengguna Internet Indonesia: Infografis Penetrasi dan Perilaku Pengguna Internet Indonesia”, Hasil Survey, 2016.

Asosiasi Penyelenggara Jasa Internet Indonesia. "Pertumbuhan Pengguna Internet Indonesia: Infografis Penetrasi dan Perilaku Pengguna Internet Indonesia”, Hasil Survey, 2017.

Bapat. "Exploring the Antecedents of Loyalty in the Context of Multi-Channel Banking", International Journal of Bank. Marketing 35, no. 2 (2017): 174-186.

Berry, L.L. "On Great Service: a Framework for Action”, Free Press. New York: n.p., 1995.

Boakye, K.G., V.R. Prybutok, and C. Blankson. "An Integrated Model of Quality for Mass Services in the Context of the Ghanaian Retail Banking Sector", Thunderbird International Business Review 58, no. 5 (2016): 425-438.

Brady, M.K. and J.J. Cronin, Jr. "Some New Thoughts on Conceptualizing Perceived Service Quality: a Hierarchical Approach", Journal of Marketing 65, no. 3 (2001): 34-49.

Brun, Rajaobelina Ricard. "Online Relationship Quality: Testing an Integrative and Comprehensive Model in the Banking Industry", Journal of Relationship Marketing 15, no. 4 (2016): 
219-246.

Caceres, R.C. and N.G. Paparoidamis. "Service Quality, Relationship Satisfaction, Trust, Commitment and Business-to-business Loyalty", European Journal of Marketing 41, no. 7/8 (2007): 836-867.

Crosby, P.B. Quality is Free: the Art of Marketing Quality Certain. n.p.: Mc Graw Hill Book Company, 1979.

Curtis. "Customer Satisfaction, Loyalty, and Repurchase: MetaAnalytical Review, Theoretical, and Empirical Evidence of Loyalty and Repurchase Differences", NSU Library, 2009.

Dick, A.S. and K. Basu. "Customer Loyalty: toward an Integrated Conceptual Framework", Journal of the Academy of Marketing Science, 1994.

Ghozali, I. and H. Latan. Structural Equation Modeling: Teori, Konsep, dan Aplikasi dengan Program Smart PLS 2.0. Semarang: Badan Penerbit Universitas Diponegoro, 2011.

Hair, J.F., J.G.T.M. Hult, C.M. Ringle, and M. Sarstedt. "Partial Least Squares Structural Equation Modeling (PLS-Sem)”, 2014.

Hemmasi, M., K. Strong, and S. Taylor. "Measuring Service Quality for Strategic Planning and Analysis in Service Firms", Journal of Applied Business Research 10, no. 4 (1994): 24.

Joseph, M. and G. Stone. "An Empirical Evaluation of US Bank Customer Perceptions of the Impact of Technology on Service Delivery in the Banking Sector", International Journal of Retail and Distribution Management 31, no. 4 (2003): 190202.

Kotler, P. and K.L. Keller. Marketing Management Organization, Volume 22, 2006. 
Kotler, P. and K.L. Keller. Marketing Management Organization, Volume 22, 2006.

Liu, Guo, and Lee. "The Effects of Relationship Quality and Switching Barriers on Customer Loyalty", Journal of Information Management, 2010.

Mullatahiri, Abdullahu and Podvorica. "The Approach of Local Firms towards e-Banking, Iliria International Review, no. 1 (2015): 149-161.

Oliver, R. Satisfaction: a Behavioral Perspective on the Consumer. New York: Mc Graw Hill International Editions, 1997.

Parasuraman, A., V.A. Zeitham, and L.L. Berry. "A Conceptual Model of Service Quality and Its Implication for Future Research", Journal of Marketing 49, no. 4 (1985).

Rahman, M.A., C.Y. Wan, and M.F. Ramli. "Relationship Quality as Mediator between Perceived Value and Customer Loyalty: Evidence from Dual-Window Banks in Northern Peninsular Malaysia", Ponte 72, no. 12 (2016): 370-379.

Reichheld, F.F. and K. Aspinall. "Building High-Loyalty Business System", Journal of Retail Banking 15, no. 4 (1993): 21-9.

Sakai, M. "Establishing Social Justice through Financial Inclusivity: Islamic Propagation by Islamic Saving and Credit Cooperatives in Indonesia", TRaNS: Trans-Regional andNational Studies of Southeast Asia 2, no. 2 (2014): 201-222.

Sakti, A. "Mapping of Conditions and Potential of BMT: Partnership to Expand the Market and Linkage of Islamic Banking Service to Micro Enterprise", Jurnal al-Muzara'ab 1, no. 1 (2013): 1-18.

Sorooshian, S. Salimi, M. Salehi, M. Nia, N. Bekheir, Asfaranjan, and Y. Sazmand. "Customer Experience about Service Quality in Online Environment: a Case of Iran", Journal of Procedia, 
Ekawati Rahayu Ningsih, dkk.

Social and Behavioral Sciences 93, no. 1 (2013): 168-169.

Vilares, J.M. and S.P. Coelho. "The Employee-Customer Satisfaction Chain in the ECSI Model", European Journal of Marketing 37, no. $11 / 12$ (2003): 1.703-1.722.

Wardono. "The Antecedent Factors on e-Loyalty Affecting the Generation Y in e-Commerce: a Cross-Cultural Study", Graduate Program in Economics Faculty of Economics and Business Universitas Indonesia Jakarta, 2015.

Yeow, A. and W.K. Lim, "KOMIDA: Making Microfinance Digital in Indonesia: Theacing Case", Thirty Ninth International Conference on Information System, San Francisco, 2018. 